\title{
Major Salivary Gland Cancer pT3 TNM Finding v8
}

National Cancer Institute

\section{Source}

National Cancer Institute. Major Salivary Gland Cancer pT3 TNM Finding v8. NCI

Thesaurus. Code C132749.

Major salivary gland cancer with tumor more than $4 \mathrm{~cm}$ in greatest dimension, and/or tumor having extraparenchymal extension. Extraparenchymal extension is clinical or macroscopic evidence of invasion of soft tissues. Microscopic evidence alone does not constitute extraparenchymal extension for classification purposes. (from AJCC 8th Ed.) 